\title{
Identifying Effective Management Instruments and Human Behavioural Changes to Manage Energy Use and Abate Emissions at Firm Level
}

\author{
Ali Ahmed Ali Almihoub ${ }^{1}$, Joseph M. Mula ${ }^{1} \&$ Mohammad Mafizur Rahman ${ }^{1}$ \\ ${ }^{1}$ School of Accounting, Economics and Finance, Faculty of Business and Law, University of Southern \\ Queensland, Australia \\ Correspondence: Ali Ahmed Ali Almihoub, School of Accounting, Economics and Finance, Faculty of Business \\ and Law, University of Southern Queensland, Australia. Tel: 61-43-419-5770. E-mail: ali.almihoub@usq.edu.au
}

Received: March 25, 2013 Accepted: April 29, 2013 Online Published: June 1, 2013

doi:10.5539/jsd.v6n7p1 URL: http://dx.doi.org/10.5539/jsd.v6n7p1

\begin{abstract}
Despite recent efforts to reduce the growth of greenhouse gas emissions (GHGs) at the national level, the negative environmental impacts of GHGs are likely to increase more in the future, especially at the level of the company. This paper presents an extension to current integrated management efforts with traditional assessments to improve current situations. The extension can be used to determine strategies of cost-effectiveness to control emissions and achieve environmental goals in reducing concentrations of GHGs. Methods developed to demonstrate significant cost savings in companies and sectors are command and control (CAC), and innovation; these instruments can contribute to the allocation of emission controls when market instruments do not fully work. To achieve further GHG emission reductions, improvements to behavioural change regarding the use of energy are an emerging area of research that has significant implications for policy. There is increasing evidence that human behaviour has been producing environmental problems. This paper introduces elements and interventions that could affect that behaviour. Governments and businesses have agreed that there is a need for more emphasis on proper assessment of behavioural change interventions. Therefore, increasing efficiency and reducing barriers within marginal abatement cost curves (MACCs) has improved the results for the management of abatement energy and emissions at firm level.
\end{abstract}

Keywords: command and control, innovation, behaviours change, efficiency and MACC barriers

\section{Introduction}

There are many pressures on companies to measure and manage their emissions of GHG not only from regulators, but also from the market. Many clients and investors are interested in not harming the environment and not just by buying products and obtaining services that have minimal effects on GHGs, but may even be motivated to boycott firms that do not reduce emissions of GHGs on their own (Pachauri, 2001).

There are a number of opportunities available to support the effective quantification and verification of GHG emissions. Organisations can take the necessary measures to achieve these opportunities to improve understanding of potential impacts of GHGs while providing a sound basis for GHGs management strategies in the future (Bryan \& Savitz, 2011). Science and advanced technologies are needed to reliably measure GHG emissions, regardless of geography, sector, or source (Reiner, Liang, Sun, Zhu, \& Li, 2007).

In 1992 the first environment management system standard was created and called British Standard 7750 (Kirchenstein \& Jump, 2006). It was followed by an international environment management system standard (ISO14000). This standard has a series of international standards in environmental management. ISO 14000 has provided a framework for the development of the system and underpinning audit program. Also, ISO has developed 14064, a standard for accounting for GHGs (ISO standard on accounting for GHG emissions). Organisations need to deem the advantage of utilising both standards as a means of achieving their goals of environmental management, and they need access to objective external audit evidence to achieve these goals (Jackson, 1997; Omer, 2008).

Understanding technology, science and methods are increasingly important in supporting climate programs, improving public understanding of climate change and its potential impacts, and creating a solid base for 
mitigation measures in the future (Baker, Chon, \& Keisler, 2009; Bryan \& Savitz, 2011). On a larger scale, this requires a variety of measuring and monitoring methodologies that can be applied to a range of sources to be used in different geographical regions and economic sectors (Almihoub, Mula, \& Rahman, 2013; Lemon, Chave, Lampa, Fissel, \& Buermans, 2004). There will be a need for information technology infrastructure and support programs to provide acceptable accuracy of results at a reasonable cost (Wexelblat \& Srinivasan, 1999).

In climate change studies, another important issue is the influence of technological change on abatement costs, as indicated in the work of Gillingham, Newell, and Pizer (2008), Clarke et al. (2008), and Weyant (1993). Technological changes play important roles in mitigation of GHGs. These reflect energy efficiency efforts in sectors to help cut business costs, reduce dependency on energy imports and abate GHG emissions (Böhm \& $\mathrm{GmbH}, 2006$ ). The Figure (1) illustrates the program used by firms to manage instruments and human behaviours change to achieve energy efficiency as well as emission reduction.

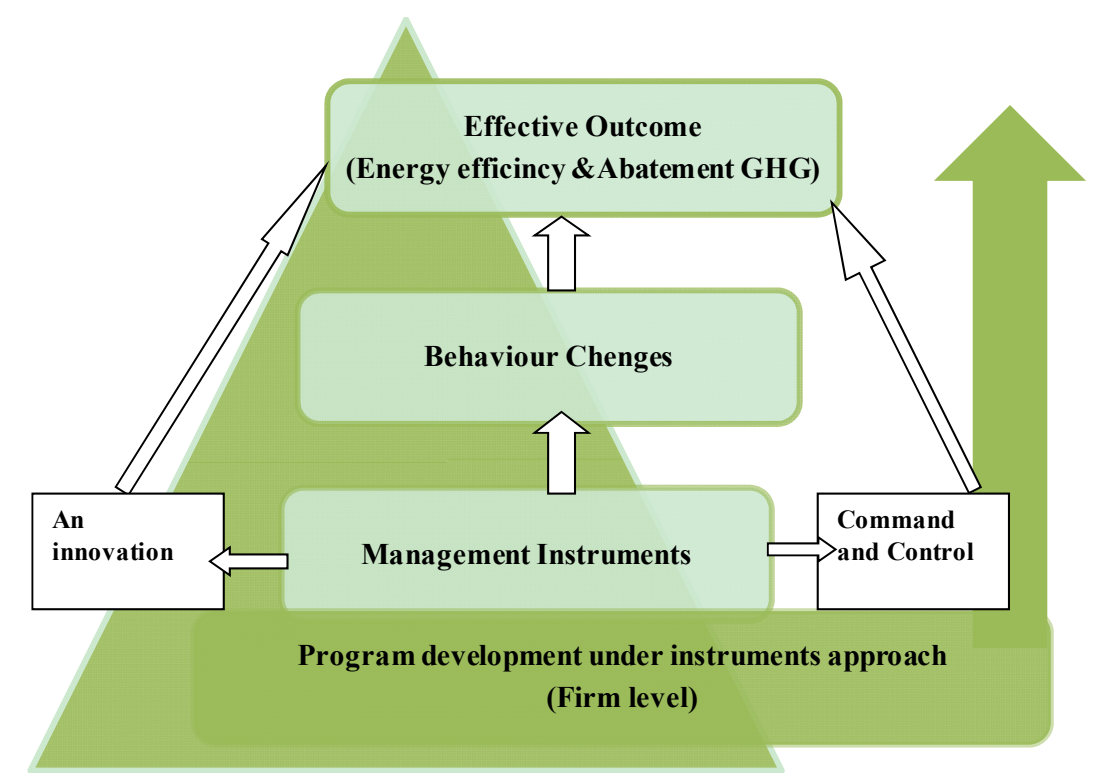

Figure 1. Program development under the instruments oriented approach

Instruments and tools play an important part and significantly function to reduce a firm's energy and emissions. One of these tools is the Command and Control (CAC) method which is a management method for controlling emissions.

\section{Command and Control}

Environmental issues are of great interest to many governments as they look for solutions to environmental problems. A scientific system for management of energy is supported by a broadly accepted methodology which may help governments formulate logical objectives for energy savings and emission reductions (Liu et al., 2011). CAC regulations may be one of these methods. CAC regulations can be defined as a way by which courses of action needed are determined and punishments associated with noncompliance are administered (Jaccard, Nyboer, \& Sadownik, 2002). It is essential to note that costs of different types of policies (CAC or market-based) may also vary (Lehmann, 2011).

In the past, governments used CAC policies as a major strategy to control pollution (Lehmann, 2012). CAC strategies can be appropriate complements to policies for pollution control (Jaffe et al., 2005; Lehmann, 2011). A study in Japan has found that a CAC method is likely to be able to provide regulated companies with motivation to increase new and creative technologies for controlling pollution (Hamamoto, 2006). CAC approaches are likely to provide companies with flexibility in selecting pollution abatement technologies and motivate them to increase their efforts in developing cost-efficient methods to control their emissions (Hamamoto, 2006). Enhancing the level of technology requires strengthening local R\&D. Also, global technologies can help the process (Liu et al., 2011). On the other hand, organisations may not adopt this policy, regardless of its environmental benefits. The reason behind this is that managers might focus on profitability of their businesses rather than the environment (Liu et al., 2011). For some time people have believed that market-based methods 
(taxes, tradable permits) are better than the CAC method (Lehmann, 2012). Therefore, in order to gain more improvements, firms can use innovations or interventions to enhance their environmental conditions.

\section{An Innovation}

It is broadly known that environmental innovations decrease marginal abatement costs. Porter hypothesises that it is possible to judge technological innovation by analysing R \& D efforts and productivity changes within existing regulations of the environment (Hamamoto, 2011; Lanoie, Patry, \& Lajeunesse, 2008). This hypothesis has been supported by many studies which have provided empirical support (Hamamoto, 2006; Kammerer, 2009; Lanoie et al., 2008). Palmer, Oates, and Portney (1995) state that environmental innovation may decrease the marginal abatement cost at all levels of pollution. Moreover, Jaffe, Newell, and Stavins (2005) found that technological innovations normally reduce the marginal cost of pollution per unit. In Japan, Hamamoto (2006) identified significant relationships between innovation activity and both total factor productivity and environmental regulations. By measuring environmental innovation, Brunnermeier and Cohen (2003) statistically found an important relationship between pollution abatement costs and environmental innovation. On the other hand, some believe that environmental innovation may not necessarily reduce the marginal cost of pollution abatement (Almihoub et al., 2013; Bréchet \& Jouvet, 2006).

It is important to note that innovation can be categorised into four types. In relation to energy, the first type (Type I), innovation is considered as an increase in the ratio of energy use over emissions. The other two types of innovation are Type II and Type III. They are broadly recognized (in industrial organizations) as process innovation/research and development. In the last form, Type IV, innovation may reduce any extra emissions beyond the limit imposed, with the objective of the firm reflecting abatement costs explicitly (Amir, Germain, \& Van Steenberghe, 2008). It is observed that innovation may be seen from different sides. From the above discussion, it can be surmised that most previous innovation studies have focused on industrial companies. However, there is still much to be done in some areas to achieve the desired results required such change consumer behavior effectively towards sustainability (Csutora \& Zsóka, 2011).

\section{Behavioural Change}

Human behaviour is the way people behave in society, both socially and environmentally. Human behaviour can be understood by drawing on a number of scientific disciplines such as psychology, sociology, behavioural economics and neuroscience (Allen, 2012). During recent years, behaviour change has gained attention in politics with the House of Lords, Science and Technology Select committee's commission of inquiry on changing of behaviour and the establishment of the Cabinet Office Behavioural Insights team (Kaplowitz, Thorp, Coleman, \& Kwame, 2012; Steg \& Vlek, 2009). Any analysis needs to weigh up costs and benefits. Estimating the cost-effectiveness of the full range of costs and benefits of different strategies needs to include effects of social as well as business costs and benefits.

Various studies of environmental behaviour assume that individuals make logical choices and choose alternatives with higher benefits and lower costs (Bolderdijk, Steg, Geller, Lehman, \& Postmes, 2012; Steg \& Vlek, 2009). The Theory of Planned Behaviour (TPB) could successfully explain different types of environmental behaviour including the choice of travel method (Kaiser \& Gutscher, 2006; Schade \& Schlag, 2003), household recycling (Taylor \& Todd, 1995), waste composting (Mannetti, Pierro, \& Livi, 2004), purchasing power-saving light bulbs, use of paper, use of water, consumption of meat (Harland, Staats, \& Wilke, 1999), and general behaviour that is pro-environment (Kaiser \& Gutscher, 2006).

Assessing the effectiveness of interventions is very important and needs systematic assessment of the effects of interventions. Until now, most studies have focused on assessing informational strategies; modi operandi have been studied and effectiveness of structural strategies has also been adopted (Abrahamse, Steg, Vlek, \& Rothengatter, 2005; Schultz, Oskamp, \& Mainieri, 1995). However, to the extent that organisational structures and incentives strongly influence community environmental behaviour, structural strategies may be more effective in promoting pro-environmental behaviour. In this respect, it should be noted that there are some important elements of behavioural changes that should be taken into considerations such as acceptance of behavioural change, knowledge and attitudes as shown in Figure 2. 


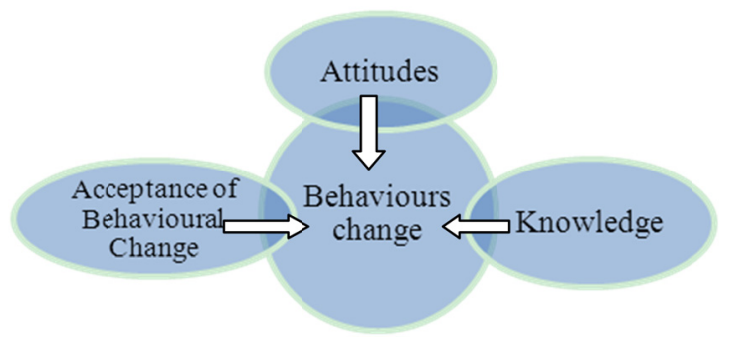

Figure 2. Elements used to understand behavioural change

Studies should be aimed at evaluating the effectiveness of intervention using experimental research designs that reveal the effectiveness of an intervention as well as packages of interventions and one with more "treatment" groups and a control group for comparison. Interventions may not only have short-term effects (Abrahamse et al., 2005), they may also have effects in the long-term study. Most effects measure and only focus on changes in environmental behaviours. Firstly, it is important to monitor the changes in behavioural determinants because this increases understanding of what was a successful intervention program or not. Secondly, it is important to monitor the changes in environmental impact, because this is the ultimate goal of behavioural interventions. Thirdly, one could get to know changes in people's quality of life, which is a significant constituent of a broader concept of sustainable development. Until now, most studies have examined (Steg \& Gifford, 2005) and anticipated changes to quality of life, but rarely are any studies used for actual changes to environmental policy change and/or to create a human behaviour policy. There are differences from anticipated changes and the actual changes in the perceived quality of life. One hypothesis is that environmental policies could not significantly decrease the quality of life of people much, at least not in the long term. Individuals adapt to changes in their lives positively or negatively by changing their standards, aims and anticipations (Diener, 2000; Ormel, Lindenberg, Steverink, \& Vonkorff, 1997). Thus, despite the fact that environmental policies may change perceptions of quality of life in the beginning, individuals can adapt or undo change.

Assessment studies using experimental designs are generally expensive and time-consuming (Steg, Dreijerink, \& Abrahamse, 2006). This may not always be possible. However, these assessment studies did not only reveal systematic evaluation to the extent to which the intervention succeeded in changing behaviour and reducing the environmental impact, but also not explain why it was unsuccessful, and how it can be adapted to increase effectiveness of intervention (Abrahamse et al., 2005). They informed the need for business to improve or replace the behaviour of a particular intervention. Moreover, it enables such businesses to provide feedback to the targeted population and to inform them of the effectiveness of efforts to improve the quality of the environment (Abrahamse, Steg, Vlek, \& Rothengatter, 2007). This may enhance the commitment to change their behaviour, and to keep the changes that have already been implemented.

Many researchers have studied environmental effectiveness as they perceive them and accept environmental policies before they are implemented, particularly in the field of travel (Loukopoulos, Jakobsson, Gärling, Schneider, \& Fujii, 2004; Schade \& Schlag, 2003; Steg \& Schuitema, 2007), but also in the use of energy (Steg $\&$ Gifford, 2005). Most studies have examined individual factors related to the perceived effectiveness or acceptance provisions. These studies show, among other things, that strategies are more satisfactory when they are thought to be more just, and when they do not have a serious impact on individual freedom. Furthermore, people who are very aware of the problem and feel a strong ethical responsibility to reduce the problem are more accepting of policies. A few studies have examined the effectiveness of perceived acceptance of features and specific policies such as rewards or sanctions, or the type of behaviour being targeted (Poortinga, Steg, Vlek, \& Wiersma, 2003; Steg et al., 2006). Policies that increase the attractiveness of pro-environment behaviour are more effective and acceptable strategies and aimed at reducing attractiveness of environmentally harmful behaviour (Steg et al., 2006). Additionally, people desire policies to enhance the adoption of energy-efficient approaches rather than policies aimed at decreasing the use of current equipment (Poortinga et al., 2003; Steg et al., 2006).

It is some time possible to make pro-environment instead of cost-effective because external barriers for environmental work (Stern, 1999). Therefore, circumstances may need to changes. These are choices in behavioural so as to increase employment opportunities individual pro-environment and to make choices in behaviour towards pro-environment relatively more attractive (Stern, 1999; Thøgersen, 2005). 


\subsection{Acceptance of Behavioural Changes}

Energy use is widespread, and this leads to an increase of energy demand. Although many efforts have been expended to make changes more friendly towards environmental sources of energy, fossil fuels are still the major source of energy, resulting in negative environmental influences. There is a need to reduce the use of energy down to the level of a company to achieve goals of sustainable energy, as well as other policies. Reductions of energy consumption can be achieved by using energy more efficiently such as investment in energy-efficient appliances, conservation energy measures, and through the adoption of energy-efficient lifestyle and in short, by changing user behavior.

Climate change and energy use issues that trigger universal social transformation processes and technology, which are based on new technologies such as energy savings, low-carbon cars and energy-saving building technologies (Ulli - Beer, Gassmann, Bosshardt, \& Wokaun, 2010). In order to avoid costly change processes, resulting from independent and radical results from market forces, key decision makers visualise and manage the path of ecology effectively. So, sufficient transition management models are critical, particularly to the growth of understanding in the processes which affect the acceptance of new technologies.

A behavioural change is almost considered a social behaviour change. Social behaviour patterns and social balance are often used as guided stable values such as social norms. However, behavioural change may change environmental conditions (such as climate warms, and the scarcity of resources) and requires acceptance of new technologies. Antecedents of behaviour change are changes in overall value that can be reached in advance when they show new patterns of behaviour and social balance in states.

There are many studies that have shown that acceptance of options relating to energy savings could be more pronounced in groups of higher education (Gilg, Barr, \& Ford, 2005; Olsen, 1983; Rohde, Dütschke, Gigli, \& Bles, 2012). The result in Poortinga et al. (2003) suggest that acceptance to reduce energy use behaviour was much higher in the lower groups of education. On the other hand, people with higher education seem to be more willing to invest in energy-efficient appliances. However, research has shown that in most cases, an increase in knowledge and awareness has not led to pro-environment behaviour (Kollmuss \& Agyeman, 2002). Furthermore, nowadays, most of the environmental non-governmental organizations (NGOs) still base communications' campaigns and strategies on the assumption that the simplification of more knowledge will lead to more enlightened behaviour.

There is much evidence to suggest that earlier financial incentives can actually compete with the feelings of civic responsibility. Frey, Heise, Stahlberg, and Wortmann (1987) found that financial incentives may actually discourage the types of behaviours needed to solve social problems such as global climate change. Almost all environmental issues involve some public good. Behavioural experiments show that social good may undermine mere mention of money. In contrast to most of the policy recommendations, economists rely on cash incentives to address the problems of collective choice. This can have adverse effects. Several environmental scientists have proven (Gowdy, 2008; Norton, 2005; O'neill, 1993) when giving individuals shared accountability that are directly attractive to the sense of the common good, these could be more effective ways to gain acceptance to alleviate climate change and other environmental strategies.

Behavioural changes can be an important element in reducing emissions of GHGs and the fight against climate change. Basic criteria used in some studies' research reports and case studies are that behaviour change: a) must be the result of the individual workers being a part of the decision making process; and, b) has results that have a clear link and are directly related with low GHGs emissions (for example, low power consumption). Thus, any action those individual workers have changed from previous work lead to a reduction in GHG emissions. Therefore, this relates to behaviour change (Ezra \& Doppelt, 2009).

Fossil fuels are the main source of energy in the United States, Australia and most other industrialised nations nowadays, which means GHG emissions are common (Ezra \& Doppelt, 2009; Gardner, Szatow, Horn, \& Quezada, 2009). Since the first round of the oil crises in the 1970s, academic researchers, utility companies, business managers and others spent a great deal of time and energy studying how to find ways to reduce the use of fossil fuels. Most of the studies concentrated on improving energy efficiency in building (Abrahamse et al., 2005; Stern, 1992). There have been some successes. The vast majority of research described in this section did not directly measure changes in GHG emissions pertaining to behaviour change (with a few notable exceptions); the research recorded all changes in energy consumption, which is assumed to be a surrogate for the reduction for GHGs. Because the vast majority of previous research has focused on reducing energy by families and organisations, it is important to examine these areas. Reducing GHGs emissions through reductions in household 
energy and regulatory conditions includes a wide range of related interventions that stimulate behavioural changes.

An important first step in motivating people to change their behaviour deliberately is to capture their time and attention. However, what happens after someone gives their time and attention to the issue is the focus of many research topics. To get people to focus on and participate in a program to reduce energy requires significant behavioural changes; therefore, intervention required methods to attract attention. The methods adopted were at least five primary approaches to attract attention and secure commitment of time: 1) door-to-door 'to seek' (Winett et al., 1985); 2) mailed information about the project or campaign (Schultz, Nolan, Cialdini, Goldstein, \& Griskevicius, 2007); 3) talking to people on the phone (for example, Baker, 1978; Department of Environment and Heritage, 2005); 4) placing ads (for example, Hayes and Cone, 1981); and 5) taking advantage of Social (Stern, 2002). As a result, obtaining commitments of time and attention is important because many of the interventions that have been developed to reduce emissions of GHGs by changing behaviour require a high level of preparation. Conscious knowledge of new information by individuals relies on subconscious simple operations, such as stimuli and response mechanisms. These operations require some cognition "open" to the researcher or practitioner to work with. This is critical "open" to get important benefits for the interventions.

The negative impact-oriented and complex environmental research demonstrates multiple behavioural motivation to use energy (Guagnano, Stern, \& Dietz, 1995; Lorenzoni, Nicholson-Cole, \& Whitmarsh, 2007). Also a range of internal and external barriers that limit the pro-environmental value of the work relationship (Kollmuss \& Agyeman, 2002). Thus, effects on the environment reflects the importance of behaviour such as energy use, which Stern (2000) sums as 'attitudes, values and beliefs - relating to the environment, but also to other considerations including comfort, aesthetics, quality, time spent with family, and so on. A second important step is contextual forces. They include sources such as social, economic, institutional and political factors, then personal capabilities (e.g., knowledge and skills). Finally the above is intended to evolve into subliminal habits that will lessen environmental influence.

\subsection{Knowledge}

Although studies found that knowledge is not the only element of the decision to enter into pro-environmental behaviour, knowledge plays an important role (Marcell, Agyeman, \& Rappaport, 2004). Can a general misunderstanding lead to a complexity issue of environmental problems and make important barriers to behaviour change and education (Oleckno, 1995). There is knowledge that user's behaviour has a significant impact on energy use. Also, saving potentials possibly from a technological point of view are dependent on user behaviour. A large number of studies on technical possibilities allows new technologies more potential energy savings. It is clear that energy consumption also depends on attitudes, preferences, and income as well as relative prices (Kriström, 2008). The difference between varying energy usage and the difference between behaviours of energy users are little known.

Kaiser, Wölfing, and Fuhrer (1999) state that factual knowledge could be seen as realistic for any attitude, and therefore, the relationship between factual knowledge and behaviour can be mediated intention as well. Furthermore, personal norms also broker the standards and values of at least one, according to intent and thus predictable behaviour indirectly. Because of these interrelationships and results of research in the environmental field, each fit with each other well. Therefore increase in awareness or knowledge may lead to change in energy use behaviours, which, in turn can lead to decreases in consumption (Hargreaves, Nye, \& Burgess, 2010).

Hines, Hungerford, and Tomera (1986) have published "Model of Responsible Environmental Behaviour", which is based on a theory of planned behaviour created by Ajzen and Fishbein, a meta-analysis on many previous studies' pro-environmental behaviour research (Icek \& Fishbein, 1980; Hines et al., 1986; Kollmuss \& Agyeman, 2002; Sia, Hungerford, \& Tomera, 1986). They found that there are variables associated with responsible pro-environmental behaviour that: Firstly, knowledge of issues, which is the person must be familiar with environmental problems and its causes. Secondly, knowledge of business strategies which is the person that knows how to or has to work to reduce his or her impact on the environmental problems. The locus of control will stem from the individual's perception of his/her ability to bring about change through his/her own behaviour. People who suffer from powerful pro-environmental attitudes are more likely to engage in pro-environmental behaviour; however, the relationship between attitudes and actions proved to be weak. Verbal commitment which is the willingness to take action to inform also gave some pointers on a person's willingness to engage in pro-environment behaviour. Finally, people who have a greater sense of personal responsibility are more likely to be engaged in environmentally responsible behaviour. 


\subsection{Attitudes}

Knowing the attitude of people towards the use of technology is important as an individual's emotional reaction can affect the use of the technology implemented (Venkatesh, Morris, Davis, \& Davis, 2003). Though attitudes are not only responsible for prediction of pro-environmental behaviours, attitudes have an influence on the selection of sustainable behaviour. It is not easy to encourage change in environmental behaviour if people do not see their behaviour makes a difference (Rydin \& Pennington, 2000). It is also difficult to see, hear, touch, or smell the effects of climate change on a regular basis or ascertain that daily volatility in weather directly impacts climate change; it is difficult to see how one change in behaviour makes a difference in GHG emissions (Marcell et al., 2004). This may indicate that the social marketing program was more effective in changing behaviour in electricity use, transfer of knowledge on climate change, and improving attitudes toward taking action to avoid or reduce GHG (Marcell et al., 2004).

The change-oriented approach opens up the 'black box' of behaviour, and is supposed to change the behaviour that occurs if people are motivated and enabled to change. This approach has focused on the factors that motivate people to change their behaviour (Venkatesh \& Morris, 2000). This is named 'stimulus' factors, which are awareness, knowledge, attitude, social and personal norms, and self-efficacy (Bo Dahlbom, Heather Greer, Cees Egmond, \& Ruud Jonkers, 2009). These factors could lead to an intention to implement the desired behaviour. These are internal and intrapersonal factors.

An alternative theoretical approach that might be called, in the broadest sense, 'attitude approach' analyses, and is another way for thought or cognitive behaviour precedents to guide behaviour. From this theoretical perspective, different models have been proposed, for instance, value 'attitude' behaviour model (Guagnano et al., 1995; Hsieh, Rai, \& Keil, 2008; Taylor \& Todd, 1995), the theory of reasoned action and its successor, the theory of planned behavior. On the other hand, many studies are not based on the theoretical models mentioned above; therefore, it could considered as the role of socio-economics and variables of demographics (Berger, 1997), also, as the role of public environmental attitudes such as environmental concerns and environmental responsible consumption (Mannetti et al., 2004).

There are various models that have been proposed, such as technology acceptance model (TAM) (Davis, 1989; Davis, Bagozzi, \& Warshaw, 1989); these models adapted from the Theory of Reasoned Action (Icek \& Fishbein, 1980; Yang \& Yoo, 2004) provide a powerful explanation and parsimonious to accept user behaviour and usage. TAM is supposed to provide user acceptance determined by two core beliefs, which are perceived usefulness and perceived ease of use. Perceived usefulness is known as the extent (degree) to which a person believes that the person using a special technique will enhance her /his functioning, while perceived ease of use is defined as the degree to which a person believes that the use of technology will be free of effort (Davis, 1989). Therefore, durability of TAM has been established through many applications and replications (Davis, 1989; Taylor \& Todd, 1995; Yang \& Yoo, 2004).

All decisions of initial and continuing acceptance are important and deserve attention. Incompatible results have been reported from previous research. For example, it was suggested that Taylor and Todd (1995) individually tended to underestimate the importance of perceived control considerations when forming behavioural decisions to accept intention. Otherwise, Hu, Clark, and Ma (2003) note that perceived ease of use can be seen overly stressed when an individual has limited knowledge or experience through technology. From a research perspective, there is a need to continue the investigation to re-examine and reconcile these results which are inconsistent, and thus enhance the theoretical and experimental mainstay applied (Hu et al., 2003; Legris, Ingham, \& Collerette, 2003). Consequences can also benefit organizational technology management practices, for example, to enable design of effective management interventions for sustainable user acceptance.

Interestingly, the theory of TAM in the reference theory of reasoned action includes social impact through the construction of so-called subjective norm. Previous research by I. Ajzen (1991) found in the psychology subjective norm, there can be important factors and/or intention behaviour. However, TAM excludes this because of the problems of building theory and measurement (Davis et al., 1989; Venkatesh \& Morris, 2000). Subjective Norms are expected to be perceived from personal key references to performance behaviour of interest (Ajzen, 1991; Hsieh et al., 2008). Though subjective norm might be expected to be significant in determining technology acceptance, based on theory of reasoned action and the theory of planned behavior, there is empirical evidence to support the role of building somewhat mixed (Ajzen, 1985, 1991). However, most companies can minimise GHG emissions by managing efficiency barriers more appropriately (Farhat \& Ugursal, 2010). 


\section{Efficiency and MACC Barriers}

One of the most important means of reducing the growing threat of global warming, caused by human use of fossil fuels is to reduce energy use (IPCC, 2007; Solomon, 2007). According to the prevailing economic theory, barriers related to reducing energy use include market failures (Golove \& Eto, 1996). In terms of the cost to maintain or reduce energy, studies for the implementation of effective measures are not implemented because of the existence of barriers to energy efficiency, resulting in a gap that is called energy efficiency gap (Thollander \& Ottosson, 2008). A barrier could be defined as a mechanism that is supposed to prevent investment in technologies that is in each, energy-efficient and economically efficient (Csutora \& Zsóka, 2011). Therefore, the barriers related to efficiency are economic/financial barriers, behavioural barriers and organisational barriers (Gillingham, Newell, \& Palmer, 2009; Koeppel, Vorsatz, University, \& Programme. United Nations Environment, 2007; Sorrell, 2004).

In addition to the price of carbon, economic barriers and non-price barriers also need to be addressed to secure the greatest opportunities to reduce emissions that have been identified as realistically achievable by 2020 . These barriers include market structure and supply (Australia, 2010). In terms of economic barriers these involve hidden costs and overhead costs such as the cost of collecting and analysing information and disruption of production (Jaffe \& Stavins, 1994). Access to capital may result in barriers; for example, a small budget can affect investment in energy-saving technology (Rohdin \& Thollander, 2006). Why are organisation energy-efficiency measures constrained by short pay-back criteria? It can be explained by risk aversion (Sorrell et al., 2000).

Homogeneity of cost-effective energy efficiency measures are not always able to be implemented because the technology is not adopted in the company (Thollander \& Ottosson, 2008). A large body of research has documented that consumers have often obtained incomplete information about market conditions, characteristics of the technology and the implications of company behaviour (Gallaher, Delhotal, \& Petruza, 2005; Howarth \& Andersson, 1993). Major industrial relationships worldwide know that they cannot have strict control and monitoring by principles; consequently, this can result in neglect of energy efficiency measures (Jaffe \& Stavins, 1994). Negative buyers may select goods on the basis of visual aspects such as price. Good buyers know more about the energy performance of the product (Thollander \& Ottosson, 2008). Split incentives and their implementation may become less useful if the person or department cannot get the benefits of investment in energy efficiency (Jaffe \& Stavins, 1994). Therefore, to reduce economic barriers for emissions abatement, behaviour is another barrier that needs be taken into consideration.

In terms of bounded-behaviour, theoretical decisions are based on incomplete information, instead of an authentic basic rule (Simon, 1957). Opponents to change within organizations could lead to the neglect of energy efficiency measures (Sorrell, 2004). Credible information from sources that are trustworthy can provide successful energy efficiency measures (Unruh, 2000). The form of this information should be specific and simple to increase acceptability (Thollander \& Ottosson, 2008; Worrell, Ramesohl, \& Boyd, 2004). There are people in organisations with real ambition to improve energy efficiency, who would prefer to be represented by an individual within key senior management, so that people in organisations can be heard and acceptable proposals disseminated (Stern, 1992). To reduce organizational barriers, an organisation's culture can include, for example, a group of individuals carrying environmental values that encourage investments in energy efficiency (Blok, 2004). In managing real barriers, not only behavioural but also organizational obstacles may be carried out. The lack of authority within departments of energy could lead to a low priority regarding barrier issues within organizations (SPRU, 2000). Therefore, management of climate change leads to more concentrations of specific barriers on approaches and methods such as a MACC approach.

MACCs can use various methods widely with differing underlying assumptions, and discount rates assumed. Therefore, a number of possibilities for reducing emissions and costs can be estimated (Akimoto et al., 2012; Erickson, 2010). The key factors that contribute to differences between MACCs' methods include projections of baseline emissions (which include mitigation measures in the base), the availability and cost of abatement options, the time it takes for implementation of mitigation, whether the model considers demand side responses to behavioural changes, and structural adjustments in the economy such as changing the prices of energy (Amman, Rafaj, \& Höhne, 2009; Van Vuuren et al., 2009). In the energy sector, MACC research has found that models, which include behavioural change can display twice as much as the mitigation potential of models that did not include behavioural change (Amman et al., 2009).

Use of MACC methods evaluates the possibility of reducing vulnerability of many restrictions (Munasinghe, Meier, Hoel, Hong, \& Aaheim, 1996). Top-down models tend to lack specific technical details of a sector. These 
models need to assess where opportunities exist and how to mitigate potential compensation mechanisms and other funding sources that have emission reduction credits (Hoogwijk et al., 2008). However, they can exceed at reflecting economic relations between regions and between products and sectors, as well as indirect effects of activities such as compensation leak emissions between countries or sectors (Blok, 2004). Bottom-up models tend to be more useful to analyse the compensation offer, because they can easily distinguish between technologies and sectors in a manner consistent with the best of the mechanisms and methodologies regarding how to compensate maturity, how to apply a separate project, technology, and/or sector-specific actions, rather than transform the economy on a large scale (Erickson, 2010). However, the bottom-up approaches of MACCs are weak in terms of the acquisition of economic relations and indirect effects (e.g, leak); also MACCs can reduce transaction costs and unsubstantiated causes for reduction, which can offer possible compensation (Fisher et al., 2007).

Most MACC methods are subject to adoption of a path and a state of uncertainty. A MACC for any given year is assumed (either explicitly or implicitly) in world politics and technology that have taken a course from now until that year (Erickson, 2010). Procedures and policy options in the early years greatly affect the prospects of reduction potential and costs in later years (Lazarowicz, 2009). One means of solving this path dependence (as well as the uncertainty related to the underlying assumption) is to use a range of possible scenarios in the early years of the policy to generate MACCs for the analysis of alternative scenarios (EPA, 2010b; Lazarowicz, 2009). The above barriers lead to identifying difficulties that should be studied, particularly for relevant sectors and at a firm level.

\section{Conclusion}

Identifying effective instruments to manage and control GHGs emissions is an important need for firms. This is because increased concerns of firms' stakeholders require firms to provide suitable and credible ways for reducing GHGs emissions. Thus, such mechanisms as command and control, and innovation are adopted, when the allocation tools of GHGs emission controls, through the market devices do not fully work. Furthermore, human behaviour could be an important element for reducing emissions, and it needs more emphasis particularly for governments and businesses to recognize and assess behaviour change interventions. These could be appropriate tools that can assist companies to reduce emissions. Furthermore, companies can employ overall efficiency to reduce MACC barriers. Consequently, these management strategies can help to reduce energy use and GHG emissions. In the future, climate strategy is becoming an important axis in all companies' work as well as sectors. Therefore, firms should give energy use, topics relating to behaviour and emissions more attention by using effective methods that require real data to control emissions with adoption of a credible MACC approach.

\section{References}

Abrahamse, W., Steg, L., Vlek, C., \& Rothengatter, T. (2005). A review of intervention studies aimed at household energy conservation. Journal of Environmental Psychology, 25(3), 273-291. http://dx.doi.org/10.1016/j.jenvp.2005.08.002

Abrahamse, W., Steg, L., Vlek, C., \& Rothengatter, T. (2007). The effect of tailored information, goal setting, and tailored feedback on household energy use, energy-related behaviors, and behavioral antecedents. Journal of Environmental Psychology, 27(4), 265-276. http://dx.doi.org/10.1016/j.jenvp.2007.08.002

Ajzen, I. (1985). From intentions to actions: A theory of planned behavior. In J. Kuhl \& J. Beckman (Eds.), Action-control: From cognition to behavior (pp. 11-39). Heidelberg: Springer.

Ajzen, I. (1991). The theory of planned behavior. Organizational behavior and human decision processes, 50(2), 179-211. http://dx.doi.org/10.1016/0749-5978(91)90020-T

Ajzen, I., \& Fishbein, M. (1980). Understanding attitudes and predicting social behaviour.

Akimoto, K., Sano, F., Homma, T., Wada, K., Nagashima, M., \& Oda, J. (2012). Comparison of marginal abatement cost curves for 2020 and 2030: longer perspectives for effective global GHG emission reductions. Sustainability Science, 1-12. http://dx.doi.org/10.1007/s11625-012-0165-5

Allen, S. (2012). Energy Use Behaviour Change. Houses of Parliament, parliamentary office of Science \& Technology.

Almihoub, A. A. A., Mula, J. M., \& Rahman, M. (2013). Are There Effective Accounting Ways to Determining Accurate Accounting Tools and Methods to Reporting Emissions Reduction? Journal of Sustainable Development, 6(4), 118. http://dx.doi.org/10.5539/jsd.v6n4p118

Amir, R., Germain, M., \& Van Steenberghe, V. (2008). On the impact of innovation on the marginal abatement 
cost curve. Journal of Public Economic Theory, 10(6), 985-1010. http://dx.doi.org/10.1111/j.1467-9779.2008.00393.x

Amman, M., Rafaj, P., \& Höhne, N. (2009). GHG mitigation potentials in Annex I countries: Comparison of model estimates for 2020. Interim Report, International Institute for Applied Systems Analysis.

Australia, C. (2010). Low Carbon Growth Plan for Australia. Melbourne, Victoria, March 2010: Monash University.

Baker, E., Chon, H., \& Keisler, J. (2009). Advanced solar R\&D: Combining economic analysis with expert elicitations to inform climate policy. Energy Economics, 31, S37-S49. http://dx.doi.org/10.1016/j.eneco.2007.10.008

Berger, I. E. (1997). The demographics of recycling and the structure of environmental behavior. Environment and Behavior, 29(4), 515-531. http://dx.doi.org/10.1177/001391659702900404

Blok, K. (2004). The effectiveness of policy instruments for energy-efficiency improvement in firms: the Dutch experience (Vol. 15): Springer. http://dx.doi.org/10.1007/978-1-4020-2157-2

Bo Dahlbom, Heather Greer, Cees Egmond, \& Ruud Jonkers. (2009). Changing energy behaviour guidelines for behavioural change programmes. Instituto para la Diversificación y Ahorro de la Energía. Retrieved October 20, 2012, from www.idae.es

Böhm, D. C., \& GmbH, R. B. (2006). Energy and $\mathrm{CO}_{2}$ Efficiency in the European Manufacturing Sector: A Decomposition Analysis. Retrieved viewed 12 October 2011, from University of Hohenheim, Langemarckstr $\quad-\quad 9, \quad$ D-76437 Rastatt Germany Retrieved from http://www.iccgov.org/iew2009/speakersdocs/Boehm_EnergyAndCo2Efficiency.pdf

Bolderdijk, J., Steg, L., Geller, E., Lehman, P., \& Postmes, T. (2012). Comparing the effectiveness of monetary versus moral motives in environmental campaigning. Nature Climate Change. http://dx.doi.org/10.1038/nclimate 1767

Bréchet, T., \& Jouvet, P. A. (2006). Environmental innovation and the cost of pollution abatement.

Brunnermeier, S. B., \& Cohen, M. A. (2003). Determinants of environmental innovation in US manufacturing industries. Journal of environmental economics and management, 45(2), 278-293. http://dx.doi.org/10.1016/S0095-0696(02)00058-X

Bryan, H., \& Savitz, M. (2011). Foundations for Innovation: Advancing Technologies and Strategies for for Greenhouse Gas $\quad$ Emissions $\quad$ Quantification. http://events.energetics.com/NISTScripps2010/pdfs/GHGWorkshopReport

Csutora, M., \& Zsóka, Á. (2011). Maximizing the efficiency of greenhouse gas related consumer policy. Journal of Consumer Policy, 34(1), 67-90. http://dx.doi.org/10.1007/s10603-010-9147-0

Davis, F. D. (1989). Perceived usefulness, perceived ease of use, and user acceptance of information technology. MIS quarterly, 319-340. http://dx.doi.org/10.2307/249008

Davis, F. D., Bagozzi, R. P., \& Warshaw, P. R. (1989). User acceptance of computer technology: a comparison of two theoretical models. Management science, 35(8), 982-1003. http://dx.doi.org/10.1287/mnsc.35.8.982

Diener, E. (2000). Subjective well-being: The science of happiness and a proposal for a national index. American psychologist, 55(1), 34. http://dx.doi.org/10.1037/0003-066X.55.1.34

EPA, U. S. (2010b). EPA Analysis of the American Power Act in the 111th Congress, Office of Atmospheric Programs, Retrieved from www.epa.gov/climatechange/economics/economicanalyses.html

Erickson, P. (2010). Estimates of Future Supply of International Greenhouse Gas Offsets: A Critical Review.

Ezra, M. M., \& Doppelt, B. (2009). Reducing greenhouse gas emissions through behavioral change. Institute for a Sustainable Environment.

Farhat, A. A. M., \& Ugursal, V. I. (2010). Greenhouse gas emission intensity factors for marginal electricity generation in Canada. International Journal of Energy Research, 34(15), 1309-1327. http://dx.doi.org/10.1002/er.1676

Fisher, B., Nakicenovic, N., Alfsen, K., Morlot, J. C., De la Chesnaye, F., Hourcade, J. C., ... Matysek, A. (2007). Issues related to mitigation in the long term context. Climate Change, 169-250.

Frey, D., Heise, C., Stahlberg, D., \& Wortmann, K. (1987). Psychologische Forschung zum Energiesparen. 
Angewandte Sozialpsychologie. Konzepte, Ergebnisse, Perspektiven, 275-289.

Gallaher, M., Delhotal, C., \& Petruza, J. (2005). Region-specific marginal abatement costs for methane from coal, natural gas, and landfills through 2030. Greenhouse Gas Control Technologies, 1. http://dx.doi.org/10.1016/B978-008044704-9/50086-0

Gardner, J., Szatow, T., Horn, M., \& Quezada, G. (2009). Sustainable Living: A Review of Behavioural Influences and Policy Options for Australia.

Gilg, A., Barr, S., \& Ford, N. (2005). Green consumption or sustainable lifestyles? Identifying the sustainable consumer. Futures, 37(6), 481-504. http://dx.doi.org/10.1016/j.futures.2004.10.016

Gillingham, K., Newell, R. G., \& Palmer, K. (2009). Energy efficiency economics and policy: National Bureau of Economic Research. http://dx.doi.org/10.3386/w15031

Gillingham, K., Newell, R. G., \& Pizer, W. A. (2008). Modeling endogenous technological change for climate policy analysis. Energy Economics, 30(6), 2734-2753. http://dx.doi.org/10.1016/j.eneco.2008.03.001

Golove, W. H., \& Eto, J. H. (1996). Market barriers to energy efficiency: a critical reappraisal of the rationale for public policies to promote energy efficiency. LBL-38059. Berkeley, CA: Lawrence Berkeley National Laboratory. http://dx.doi.org/10.2172/270751

Gowdy, J. M. (2008). Behavioral economics and climate change policy. Journal of Economic Behavior \& Organization, 68(3), 632-644. http://dx.doi.org/10.1016/j.jebo.2008.06.011

Guagnano, G. A., Stern, P. C., \& Dietz, T. (1995). Influences on attitude-behavior relationships a natural experiment with curbside recycling. Environment and Behavior, 27(5), 699-718. http://dx.doi.org/10.1177/0013916595275005

Hamamoto, M. (2006). Environmental regulation and the productivity of Japanese manufacturing industries. Resource and energy economics, 28(4), 299-312. http://dx.doi.org/10.1016/j.reseneeco.2005.11.001

Hamamoto, M. (2011). Energy Efficiency Regulation and R\&D Activity: A Study of the Top Runner Program in Japan. Low Carbon Economy, 2(2), 91-98. http://dx.doi.org/10.4236/lce.2011.22012

Hargreaves, T., Nye, M., \& Burgess, J. (2010). Making energy visible: A qualitative field study of how householders interact with feedback from smart energy monitors. Energy policy, 38(10), 6111-6119. http://dx.doi.org/10.1016/j.enpol.2010.05.068

Harland, P., Staats, H., \& Wilke, H. A. M. (1999). Explaining Proenvironmental Intention and Behavior by Personal Norms and the Theory of Planned Behavior1. Journal of Applied Social Psychology, 29(12), 2505-2528. http://dx.doi.org/10.1111/j.1559-1816.1999.tb00123.x

Hines, J. M., Hungerford, H. R., \& Tomera, A. N. (1986). Analysis and synthesis of research on responsible pro-environmental behavior: a meta-analysis. The Journal of Environmental Educational, 18(2), 1-8. http://dx.doi.org/10.1080/00958964.1987.9943482

Hoogwijk, M. M., van Vuuren, D. P., Boeters, S., Blok, K., Blomen, E., Barker, T., ... Nabuurs, G. J. (2008). Sectoral emission reduction potentials: comparing bottom-up and top-down approaches.

Howarth, R. B., \& Andersson, B. (1993). Market barriers to energy efficiency. Energy Economics, 15(4), 262-272. http://dx.doi.org/10.1016/0140-9883(93)90016-K

Hsieh, J., Rai, A., \& Keil, M. (2008). Understanding digital inequality: Comparing continued use behavioral models of the socio-economically advantaged and disadvantaged. MIS quarterly, 32(1), 97-126.

Hu, P. J. H., Clark, T. H. K., \& Ma, W. W. (2003). Examining technology acceptance by school teachers: a $\begin{array}{lllll}\text { longitudinal study. Information } \& \text { management, } & 41(2), & \text { 227-241. }\end{array}$ http://dx.doi.org/10.1016/S0378-7206(03)00050-8

IPCC. (2007). Contribution of Working Group III to the Fourth Assessment Report of the Intergovernmental Panel on Climate Change. Summary for Policymakers, viewed 30 June 2012 http://www.ipcc.ch/SPM040507.pdf

Jaccard, M., Nyboer, J., \& Sadownik, B. (2002). The cost of climate policy (Vol. 7): Univ of British Columbia Pr.

Jackson, S. L. (1997). The ISO 14001 implementation guide: creating an integrated management system, 3. John Wiley and Sons.

Jaffe, A. B., Newell, R. G., \& Stavins, R. N. (2005). A tale of two market failures: Technology and 
$\begin{array}{llll}\text { environmental policy. } & \text { Ecological }\end{array}$ http://dx.doi.org/10.1016/j.ecolecon.2004.12.027

Jaffe, A. B., \& Stavins, R. N. (1994). The energy-efficiency gap What does it mean? Energy policy, 22(10), 804-810. http://dx.doi.org/10.1016/0301-4215(94)90138-4

Kaiser, F. G., \& Gutscher, H. (2006). The Proposition of a General Version of the Theory of Planned Behavior: Predicting Ecological Behavior1. Journal of Applied Social Psychology, 33(3), 586-603. http://dx.doi.org/10.1111/j.1559-1816.2003.tb01914.x

Kaiser, F. G., Wölfing, S., \& Fuhrer, U. (1999). Environmental attitude and ecological behaviour. Journal of environmental psychology, 19(1), 1-19. http://dx.doi.org/10.1006/jevp.1998.0107

Kammerer, D. (2009). The effects of customer benefit and regulation on environmental product innovation. Empirical evidence from appliance manufacturers in Germany. Ecological Economics, 68(8-9), 2285-2295. http://dx.doi.org/10.1016/j.ecolecon.2009.02.016

Kaplowitz, M. D., Thorp, L., Coleman, K., \& Kwame Yeboah, F. (2012). Energy conservation attitudes, knowledge, and behaviors in science laboratories. Energy policy. http://dx.doi.org/10.1016/j.enpol.2012.07.060

Kirchenstein, J. J., \& Jump, R. A. (2006). The european ecolabels and audits scheme: New environmental standards for competing abroad. Environmental Quality Management, 3(1), 53-62. http://dx.doi.org/10.1002/tqem.3310030106

Koeppel, S., Vorsatz, D., University, C. E., \& Programme. United Nations Environment, S. (2007). Assessment of policy instruments for reducing greenhouse gas emissions from buildings: CEU.

Kollmuss, A., \& Agyeman, J. (2002). Mind the gap: why do people act environmentally and what are the barriers to pro-environmental behavior? Environmental education research, 8(3), 239-260. http://dx.doi.org/10.1080/13504620220145401

Kriström, B. (2008). Residential Energy Demand. Household Behaviour and the Environment Reviewing the Evidence, 95. http://dx.doi.org/10.1787/482400015020

Lanoie, P., Patry, M., \& Lajeunesse, R. (2008). Environmental regulation and productivity: testing the porter hypothesis. Journal of Productivity Analysis, 30(2), 121-128. http://dx.doi.org/10.1007/s11123-008-0108-4

Lazarowicz, M. (2009). Global Carbon Trading: a framework for reducing emissions: Stationery Office.

Legris, P., Ingham, J., \& Collerette, P. (2003). Why do people use information technology? A critical review of the technology acceptance model. Information \& management, 40(3), 191-204. http://dx.doi.org/10.1016/S0378-7206(01)00143-4

Lehmann, P. (2011). Justifying a Policy Mix for Pollution Control: A Review of Economic Literature. Journal of Economic Surveys.

Lehmann, P. (2012). Justifying a Policy Mix for Pollution Control: A Review of Economic Literature. Journal of Economic Surveys. http://dx.doi.org/10.1111/j.1467-6419.2010.00628.x

Lemon, D., Chave, R., Lampa, J., Fissel, D., \& Buermans, J. (2004). The ASFM Monitor: a cost-effective tool for real-time measurement of turbine discharge. Proc. Hydrovision.

Liu, X., Zhu, B., Zhou, W., Hu, S., Chen, D., \& Griffy-Brown, C. (2011). $\mathrm{CO}_{2}$ emissions in calcium carbide industry: An analysis of China's mitigation potential. International Journal of Greenhouse Gas Control Retrieved March 3, 2012, from http://www.sciencedirect.com/science/article/pii/S1750583611001010

Lorenzoni, I., Nicholson-Cole, S., \& Whitmarsh, L. (2007). Barriers perceived to engaging with climate change among the UK public and their policy implications. Global environmental change, 17(3), 445-459. http://dx.doi.org/10.1016/j.gloenvcha.2007.01.004

Loukopoulos, P., Jakobsson, C., Gärling, T., Schneider, C. M., \& Fujii, S. (2004). Car-user responses to travel demand management measures: goal setting and choice of adaptation alternatives. Transportation Research Part D: Transport and Environment, 9(4), 263-280. http://dx.doi.org/10.1016/j.trd.2004.02.003

Mannetti, L., Pierro, A., \& Livi, S. (2004). Recycling: Planned and self-expressive behaviour. Journal of environmental psychology, 24(2), 227-236. http://dx.doi.org/10.1016/j.jenvp.2004.01.002

Marcell, K., Agyeman, J., \& Rappaport, A. (2004). Cooling the campus: Experiences from a pilot study to reduce electricity use at Tufts University, USA, using social marketing methods. International Journal of 
Sustainability in Higher Education, 5(2), 169-189. http://dx.doi.org/10.1108/14676370410526251

Munasinghe, M., Meier, P., Hoel, M., Hong, S., \& Aaheim, A. (1996). Applicability of techniques of cost-benefit analysis to climate change. Climate Change 1995: Economic and Social Dimensions: Contribution of Working Group III to the Second Assessment Report of the Intergovernmental Panel on Climate Change, $145-178$.

Norton, B. G. (2005). Sustainability: A philosophy of adaptive ecosystem management: University of Chicago Press. http://dx.doi.org/10.7208/chicago/9780226595221.001.0001

O'neill, J. (1993). Ecology, Policy and Politics: human well-being and the natural world: Routledge. http://dx.doi.org/10.4324/9780203416570

Oleckno, W. A. (1995). Guidelines for improving risk communication in environmental health. Journal of Environmental Health, 58(1).

Olsen, M. E. (1983). Public acceptance of consumer energy conservation strategies. Journal of Economic Psychology, 4(1), 183-196. http://dx.doi.org/10.1016/0167-4870(83)90052-1

Omer, A. M. (2008). Energy, environment and sustainable development. Renewable and Sustainable Energy Reviews, 12(9), 2265-2300. http://dx.doi.org/10.1016/j.rser.2007.05.001

Ormel, J., Lindenberg, S., Steverink, N., \& Vonkorff, M. (1997). Quality of life and social production functions: A framework for understanding health effects. Social science \& medicine, 45(7), 1051-1063. http://dx.doi.org/10.1016/S0277-9536(97)00032-4

Pachauri. (2001). Corporates and Civil Society. The Newspaper Today, Energy Research Institute (TERI), Reviewed April 4, 2012, http://www.teriin.org/features/art128.htm

Palmer, K., Oates, W. E., \& Portney, P. R. (1995). Tightening environmental standards: The benefit-cost or the no-cost paradigm? The Journal of Economic Perspectives, 9(4), 119-132. http://dx.doi.org/10.1257/jep.9.4.119

Poortinga, W., Steg, L., Vlek, C., \& Wiersma, G. (2003). Household preferences for energy-saving measures: A $\begin{array}{lllll}\text { conjoint analysis. Journal of Economic Psychology, 24(1), } & \text { 49-64. }\end{array}$ http://dx.doi.org/10.1016/S0167-4870(02)00154-X

Reiner, D., Liang, X., Sun, X., Zhu, Y., \& Li, D. (2007). Stakeholder attitudes towards carbon dioxide capture and storage technologies in China.

Rohde, C., Dütschke, E., Gigli, M., \& Bles, M. (2012). Behavioural Climate Change Mitigation Options. CE Delft, Delft.

Rohdin, P., \& Thollander, P. (2006). Barriers to and driving forces for energy efficiency in the non-energy intensive manufacturing industry in Sweden. Energy, 31(12), 1836-1844. http://dx.doi.org/10.1016/j.enpol.2006.01.010

Rydin, Y., \& Pennington, M. (2000). Public participation and local environmental planning: the collective action problem and the potential of social capital. Local environment, 5(2), 153-169. http://dx.doi.org/10.1080/13549830050009328

Schade, J., \& Schlag, B. (2003). Determinants of people's acceptability of pricing measures-replication and extension of a causal model. Acceptability of transport pricing strategies, 235.

Schultz, P., Oskamp, S., \& Mainieri, T. (1995). Who recycles and when? A review of personal and situational $\begin{array}{llll}\text { factors. Journal of environmental psychology, } & 15(2), & 105-121 .\end{array}$ http://dx.doi.org/10.1016/0272-4944(95)90019-5

Schultz, P. W., Nolan, J. M., Cialdini, R. B., Goldstein, N. J., \& Griskevicius, V. (2007). The constructive, destructive, and reconstructive power of social norms. Psychological Science, 18(5), 429-434. http://dx.doi.org/10.1111/j.1467-9280.2007.01917.x

Sia, A. P., Hungerford, H. R., \& Tomera, A. N. (1986). Selected predictors of responsible environmental behavior: an analysis. The Journal of Environmental Educational, 17(2), 31-40. http://dx.doi.org/10.1080/00958964.1986.9941408

Solomon, S. (2007). Climate change 2007: the physical science basis: contribution of Working Group I to the Fourth Assessment Report of the Intergovernmental Panel on Climate Change: Cambridge Univ Pr.

Sorrell, S. (2004). The economics of energy efficiency: barriers to cost-effective investment: Edward Elgar Pub. 
Sorrell, S., Schleich, J., Scott, S., O’Malley, E., Trace, F., Boede, E., ... Radgen, P. (2000). Reducing barriers to energy efficiency in public and private organizations. Retrieved October, 8, 2007.

Steg, L., Dreijerink, L., \& Abrahamse, W. (2006). Why are energy policies acceptable and effective? Environment and Behavior, 38(1), 92-111. http://dx.doi.org/10.1177/0013916505278519

Steg, L., \& Gifford, R. (2005). Sustainable transportation and quality of life. Journal of transport geography, 13(1), 59-69. http://dx.doi.org/10.1016/j.jtrangeo.2004.11.003

Steg, L., \& Schuitema, G. (2007). Behavioural responses to transport pricing: a theoretical analysis. Threats from car traffic to the quality of urban life: Problems, causes, and solutions, 347-366.

Steg, L., \& Vlek, C. (2009). Encouraging pro-environmental behaviour: An integrative review and research $\begin{array}{lllll}\text { agenda. Journal of } & \text { Environmental }\end{array}$ http://dx.doi.org/10.1016/j.jenvp.2008.10.004

Stern, P. C. (1992). What psychology knows about energy conservation. American Psychologist; American Psychologist, 47(10), 1224. http://dx.doi.org/10.1037/0003-066X.47.10.1224

Stern, P. C. (1999). Information, incentives, and proenvironmental consumer behavior. Journal of Consumer Policy, 22(4), 461-478. http://dx.doi.org/10.1023/A:1006211709570

Stern, P. C. (2000). Toward a coherent theory of environmentally significant behavior. Journal of social issues, 3(56), 407-424. http://dx.doi.org/10.1111/0022-4537.00175

Stern, P. C. (2002). New environmental theories: toward a coherent theory of environmentally significant behavior. Journal of social issues, 56(3), 407-424. http://dx.doi.org/10.1111/0022-4537.00175

Taylor, S., \& Todd, P. (1995). An integrated model of waste management behavior A test of household recycling and composting intentions. Environment and Behavior, 27(5), 603-630. http://dx.doi.org/10.1177/0013916595275001

Thøgersen, J. (2005). How may consumer policy empower consumers for sustainable lifestyles? Journal of Consumer Policy, 28(2), 143-177. http://dx.doi.org/10.1007/s10603-005-2982-8

Thollander, P., \& Ottosson, M. (2008). An energy efficient Swedish pulp and paper industry-exploring barriers to and driving forces for cost-effective energy efficiency investments. Energy Efficiency, 1(1), 21-34. http://dx.doi.org/10.1007/s12053-007-9001-7

Ulli - Beer, S., Gassmann, F., Bosshardt, M., \& Wokaun, A. (2010). Generic structure to simulate acceptance dynamics. System Dynamics Review, 26(2), 89-116. http://dx.doi.org/10.1002/sdr.440

Unruh, G. C. (2000). Understanding carbon lock-in. Energy policy, 28(12), 817-830. http://dx.doi.org/10.1016/S0301-4215(00)00070-7

Van Vuuren, D. P., Hoogwijk, M., Barker, T., Riahi, K., Boeters, S., Chateau, J., ... Blok, K. (2009). Comparison of top-down and bottom-up estimates of sectoral and regional greenhouse gas emission reduction potentials. Energy policy, 37(12), 5125-5139. http://dx.doi.org/10.1016/j.enpol.2009.07.024

Venkatesh, V., \& Morris, M. G. (2000). Why don't men ever stop to ask for directions? Gender, social influence, and their role in technology acceptance and usage behavior. Management Information Systems Quarterly, 24(1), 115-140. http://dx.doi.org/10.2307/3250981

Venkatesh, V., Morris, M. G., Davis, G. B., \& Davis, F. D. (2003). User acceptance of information technology: Toward a unified view. MIS quarterly, 425-478.

Wexelblat, R. L., \& Srinivasan, N. (1999). Planning for information technology in a federated organization. Information \& management, 35(5), 265-282. http://dx.doi.org/10.1016/S0378-7206(98)00093-7

Weyant, J. P. (1993). Costs of reducing global carbon emissions. The Journal of Economic Perspectives, 7(4), 27-46. http://dx.doi.org/10.1257/jep.7.4.27

Worrell, E., Ramesohl, S., \& Boyd, G. (2004). Advances in Energy Forecasting Models Based on Engineering $\begin{array}{lllll}\text { Economics. Annu. Rev. Resour., 29, } & \text { 345-381. }\end{array}$ http://dx.doi.org10.1146/annurev.energy.29.062403.102042

Yang, H., \& Yoo, Y. (2004). It's all about attitude: revisiting the technology acceptance model. Decision Support Systems, 38(1), 19-31. http://dx.doi.org/10.1016/S0167-9236(03)00062-9 


\section{Copyrights}

Copyright for this article is retained by the author(s), with first publication rights granted to the journal.

This is an open-access article distributed under the terms and conditions of the Creative Commons Attribution license (http://creativecommons.org/licenses/by/3.0/). 